\title{
Motivation to Learning: Toward Achievement
}

\section{Zahra Bouchkioua, Latifa Mokhlesse}

Department of Psychology, Faculty of Literature and Human Sciences, Mohammed V University, Rabat, Morocco

Email: zahra.bouchkioua@um5.ac.ma,latifa.mokhlesse@um5.ac.ma

How to cite this paper: Bouchkioua, Z., \& Mokhlesse, L. (2021). Motivation to Learning: Toward Achievement. Psychology, 12, 462-476.

https://doi.org/10.4236/psych.2021.123029

Received: February 24, 2021

Accepted: March 28, 2021

Published: March 31, 2021

Copyright $\odot 2021$ by author(s) and Scientific Research Publishing Inc. This work is licensed under the Creative Commons Attribution International License (CC BY 4.0).

http://creativecommons.org/licenses/by/4.0/

\begin{abstract}
This paper resumes research about failure and loss at university. Massification, failure and abandonment rates, psychological and methodological issues are challenges that students and teachers face daily. We took over the disciplinary action by questioning motivational psychology, academic educational, and methodological accompaniment contributions. Expressly, enhancing postgraduate student motivation via aware methodological training to selfregulate, cope, control, and persevere had concrete results. The sociocognitive motivation theoretical model's choice proved suitable for improving students' motivation, enhancing their learning strategies, and resolving their difficulties. The following resume results from answering the problems on which problems are due to the low studies motivation? To 2-Can methodological accompaniment for conscious training on metacognitive, managing, motivational, coping, control, and perseverance strategies modify students' motivation and mitigate their learning strategies? The experiment (conscious training at learning strategies) indicates that a part of this student's difficulties links to their learning motivation. Furthermore, the methodological accompaniment program proved a productive tool for enhancing students' motivation through metacognitive strategies.
\end{abstract}

\section{Keywords}

Sociocognitive, Coping, Metacognition, Self-Efficacy, Skills

\section{Introduction}

This paper results of research with an eventual relationship between learning motivation and freshman studies difficulties as a topic. Methodological accompaniment (Romainville, 2007) allows the possibility of concept practice. This study has theoretical and practice interests. As a context, we opt for the Faculty of Juridic Sciences where students fail, quit, and shift their scholar options. In front of these facts, it customary to examine the causes of these considerable 
wastage rates. Is it a policy problem or an insufficient capacity and efforts needful to the smoothness of the student's initial choice? By interring, the freshman has a target or a project? Do students stumble on difficulties? Are their tests correlate with the aimlessness and project shortcomings of students? Are these difficulties connector results in the lack of the working methods? Is it a problem of motivation? Countless studies around the world had to have some issues. Some researchers (Viau, 1994) attempt to respond to many aspects to converge to psycho elements considering their repercussions on the student's work (Romainville, 2000). Thus, literary devices of control failure and abandonment appeared in the Anglo-Saxon context during the 80, and more and more in Europe (Houart \& Vastersavendt, 1996) since the 90 (Michaut, 2000). Dropouts (Bernard \& Michaut, 2018) and resignation in university studies appear to be consequences of university democratization; however, others exist. (Langevin, 1996; DeKetele \& Wouters, 1993; Romainville \& Crinon, 2020). Learning difficulties and the doubt surrounding the student's orientation is part of the causes. Stress and anxiety constitute other sources of the student's surrender. Moreover, the deficiency of learning skills and methodological work, such as taking notes, reading efficiency, writing rules, exams preparation (including time, stress, and document management), account for more adaptation sources in the university. Though, failure and abandonment of academic students do not exclusively reflect via statistics. Romainville (Romainville, 2000) stipule that if we weedily concentrate on criteria's certification, we overlook to preserve with enough details learning topics student's, meaning and suitability of achievements and degree of the previous student's pieces of knowledge. The context is furnished by Absences unjustified, reasoning absence, weak reasoning, white copy, off topics, frequency and reading quality, a psychological state in classrooms, the tricky relationship between students and teachers, specifically those of hermetic modules. Learners try to do it despite the discomfort resulting from those difficulties. They had ungrounded attitudes to the regulation, the recovery, the questioning. Students offer yet the possibility to assist themselves (Delagaranderie, 1980). The aforementioned is why, according to Merieu (Merieu, 1987), it is useful to describe the failure through their apparent patterns (behavioral signs, attitudes, affective signs). In this work, analysis's failure fellow his consciousness conception, about the felling go frustration due to the gap between the pre-established target and the result. Otherwise, the consequences of abandonment and failure as withering of self-esteem whittling the success and motivation. The fail reflection educational system and the teachers' self-efficacy are at risk of losing professional motivation, feeling guilt, and failing to the burnout. Abandonment is financially expansive. Professionally, failure and abandonment affect perseveration, engagement. Ipso facto, to this study's topic, is: can we act to the student's motivation to enhance their learning strategies? This topic involves these questions: Are the students' difficulties due to their weak motivation to learn? Is methodological accompaniment aiming for conscious training to metacognitive, control, motivational, coping, and perseverance strategies to modify students' 
motivation and resolve their learning difficulties? In this study, we examine the influence of learning strategies on the student's basis. Confirmation of such relation would aid to propose tools susceptive to remedy partially students and teachers' problems.

\section{The Conceptual Framework}

This research refers to the pedagogical university, an interdisciplinary domain where various disciplines interact, including psychological motivation and learning strategies. The thread is sociocognitive definition to the concept of motivation that Bandura (Bandura, 1982a, 1982b, 1983, 1984, 1986a, 1986b, 1986c, $1988,2007,2019)$ defines as a belief in what we can do. He considers that people's self-efficacy ideas influence what they do: how they think, motivate and behave. We believe that motivation engenders interest in learning. Motivation is not a simple institutional ingredient but a quiet live story (Weidman, 1999). The propensity to the sociocognitive approach allows guiding this work because it shows how to influence life and it predicts. In this approach, thinking operation, motivation, and human action (Kozanits, 2010) depend on factors acting as regulating and motivating agents, cognitive and social competencies.

\subsection{Learning Strategies as Motivation Indicators}

Cognitive engagement (as an indicator of motivation in sociocognitive theory) is a degree of mental effort provided by the learners accomplishing their tasks. This engagement implies the use of facilitating and maintaining learning strategies. Zimmerman (Zimmerman, 1990, 2002, 2015, 2016) depicts a cognitively engaged learner as someone who performs their duties confidently and calmly, assessing what he can do. He begets a sense of responsibility toward efficiency. Benelazmia (Benelazmia, 2002) stipule that cognitive strategies reflect the learner's components personality (intellectual, affective and social). As it happens, a pupil has cognitive processes that reflect his learning strategies state (seizure, revision, updating). Metacognitive strategies (Romainville \& Crinon, 2020): A learner had a metacognitive approach if he can assess consciously his thinking working and his learning (Biemar et al., 2020), in award all that relate to planification, regulation, and revision (Palinscar, 1986; Marzano et al., 1988, Romainville, 2006). The recourse of this kind of strategy is often expressed by a global operating. Ultimately, metacognitive strategy use involves in front of difficult situations the following attitudes: 1) identify task feasibility; 2) persist against impediments, and; 3) set high goals. Affective strategies: learning required another kind of strategy, affective strategy. They are self-regulatory, whose role is to adapt emotions and feelings to learning circumstances. The student using it can concentrate on a task, managing time, and control his anxiety (Barbeau, 1993). From where a sense of responsibility, awareness, an operating mode and self-control, and task control. Control strategies: Cognitive engagement uses environmental resources requiring organization, supervision, and control. The role of control strategies, allowing developing students' skills to manage their time, 
work, rooms, sources information indispensable to their tasks, and enlist help (teachers, classmates).

\subsection{Methodological Accompaniment and Motivation}

Some researchers (Houssaye, 1993) consider the demotivated student as devoid methods. The role of the accompanist (coach) is to help the student find ways to learn. Thus, the accompanist continuously searches for creativity and opens to different approaches responding to learning circumstances, other contents, and accompanied teaching styles. The establishment of accompaniment device has a base on a triply articulated logic. (Chesnaie, 1998; Delagaranderie, 1982, 1991, 1999): 1) to give and look for mean's tasks, to create connections between them and contents (Romainville, 2006); 2) put on goal, formulate him, anticipate results, evaluate necessary means; 3 ) draw program trying to reflect about usefulness, quality, and quantity, time and action are preparing a plan. Before taking action to adjust tasks to the Arabic law student's level (Vygostky, 1978), speak in this case about Zone of Proximal Development ZPD). In other words, it is suitable to choose medium levels' tasks difficulties. An accompanied student can thus choice develop his methods so that he may face ovoid boredom and discouragement. It is propitious to split up problems to make them treatable and reachable for the accompanied student. Task analysis must take. It is especially needful to verify the accompanying interest to proposed activities-the student's formulated request to guarantee the methodological accompaniment's legitimacy. Otherwise, the accompanying consent is a minimum requirement to undertake this kind of action and expect some degree of satisfying investment. The novelty of tasks, psychologic, physiologic, and spatiotemporal factors are parameters supporting this investment. However, the prerequisites analysis is one of those essential factors building accompaniment action. Pedagogical contracts ensure student's dignity (Houart et al., 2019). This principle does not adhere to the accompaniment foundations since we cannot all predict. Following this theoretical sketch, we formulate this hypothesis: 1) lack of motivation is one student's source of difficulties; 2) a conscious training methodological accompaniment to metacognitive, control, motivational, coping, and perseverance strategies improve motivation and mitigate student's problems; 3) we can influence freshman motivation by enhancing their learning strategies.

\section{The Research Methodology}

An intervention program for the student aims to accompany them in a reflection about learning motivation and strategies. A questionnaire tool is a questionnaire elaborated to diagnose and measure learning strategies and motivation's components in pre-test and post-test. The choice of the experimental plan is justified because it allows controlling the effect of methodological accompaniment and an eventual influence of undesired variables (see Table 1: Experimental plan). This plan allows the possibility to control the impact of unexpected variables susceptible to influence experimental procedure results through witness groups. 
Table 1. Experimental plan.

\begin{tabular}{lcc}
\hline & $\begin{array}{c}\text { The motivation } \\
\text { (pre-test) }\end{array}$ & $\begin{array}{c}\text { Learning difficulties } \\
\text { (pre-test) }\end{array}$ \\
\hline The motivation & 1000 & 0.503 \\
Pearson correlation & & 0.008 \\
Sig. (unilateral) & 71 & 22 \\
N & & 1000 \\
\hline Learning difficulties & 0.503 & \\
Pearson correlation & 0.008 & 22 \\
Sig. (unilateral) & 22 & \\
N & & \\
\hline
\end{tabular}

The experimental group represents globally the experimental gait, especially program dispensation (independent variable in this study). This program was dispensed during five months (all but an academic unit), which corresponded to one pedagogical sequence (a series of steps quite distinct but linked by a constructed, coherent, and progressive tasks line aimed a conscious training to learning strategies). This sequence sits between the pre-test spent to the experimental group and final's phase witnesses group ended by the post-test pass to experimental and witnesses 1 and two groups. The research's population: Arabic jurist freshman (2014-2015 cohorts). The methodological accompaniment program fits this contest. The random sample is composed of the experimental group 1) 41 students; first witness group; 2) 36 students; second witness group; 3) 48 students.

\subsection{Collecting and Processing Data}

The questionnaire is a tool to diagnose and measure up motivation and methodological work for academic students. The questionnaire's topic is the self-efficacy sentiment as the primary motivation component, which involves these dimensions: lived experience, vicarious experience, verbal persuasion, physiological or emotional state, sentiment self-efficacy information sources. Independent variables include these dimensions and sub-dimensions: self-regulation, metacognitive, control, motivational, coping, and perseverance strategies. For the statistical analysis, we opt for SPSS software. The data collection and processing procedure we proceeded as follows: The questionnaire was distributed collectively in the classrooms, in the presence of the teachers. After a moment of explanation and confidence building, the students were encouraged to respond specifically and personally to the questions. This action lasted between 20 and 25 minutes. We carried out the pre-test during the first session of the Language and Communication sub-module of the Law sector taught in Arabic. The proposed me- 
thodological program occupied the sessions of this sub-module and was given to a single group: the experimental group. Under this sub-module (the last session before the controls), we carried out post-tests in the three groups concerned by this research. For the statistical analysis, we called on the computer tool through the use of the SPSS statistical software. This software is widely adopted by researchers in the humanities and social sciences and offers processing facilities. Following, we present the results of this treatment.

\subsection{Descriptive Statistics}

\subsubsection{The Characteristics of the Sample}

Before moving on to the presentation of the research results, this section is intended to show the homogeneity of the characteristics of the sample. Students belonging to the three constituent groups of this sample share specific characteristics. The following table shows this characteristic homogeneity.

\subsubsection{Items Relating to the Characteristics of the Sample}

Question 7. I am: $\square$ Full-time student $\square$ Civil servant $\square$ Other, (specify):

Question 8. I live in: $\square$ The university campus $\square$ With family $\square$ In co-location $\square$ Other

$82.9 \%$ of the students in the experimental group and $86.1 \%$ of the students in the control group 1 are students living with families. They are only $66.7 \%$ at the control group level 2. Statistics show that $(91.9 \%)$ of the students surveyed are full-time students and $76.0 \%$ live with families (see Table 2: The percentages on the characteristics of the sample).

\subsubsection{Factorial Analysis of the Dimensions of Motivation}

Factor analysis was performed on the dependent and independent variables' components. The methodology adopted consists of starting with factor analyzes for each set of items under the same dimension. Then, global factor analysis is carried out on the sub-dimensions which emerge from our analysis. Besides, we have chosen principal component analysis because it can explain a large part of the variance with a minimum of factors (see: Table 3: The constituents of motivation after the factorial analysis of the dimensions of motivation). The factor analysis reduced the components of motivation (lived experience, vicarious experience, verbal persuasion, emotional and physiological state, and sources of information about the Sense of Personal Effectiveness) (See Appendix).

Table 2. The percentages on the characteristics of the sample.

\begin{tabular}{ccccc}
\hline & Groupe exp & Groupe témoin 1 & Groupe témoin 2 & Total \\
\hline Full time student & $92.7 \%$ & $88.9 \%$ & $91.7 \%$ & $91.9 \%$ \\
Student live with the family & $82.9 \%$ & $86.1 \%$ & $66.7 \%$ & $76.0 \%$ \\
\hline
\end{tabular}


Table 3. The constituents of motivation after the factorial analysis of the dimensions of motivation.

\begin{tabular}{|c|c|c|c|c|c|c|}
\hline \multicolumn{7}{|c|}{ Variance totale expliquée } \\
\hline \multirow{2}{*}{ Composantes- } & \multicolumn{3}{|c|}{ Valeurs propres initiales } & \multicolumn{3}{|c|}{$\begin{array}{c}\text { Extraction sommes des carrés } \\
\text { des facteurs retenus }\end{array}$} \\
\hline & Total & $\begin{array}{l}\% \text { de la } \\
\text { Variance }\end{array}$ & Cumulés \% & Total & $\begin{array}{c}\% \text { de la } \\
\text { Variance }\end{array}$ & Cumulés \% \\
\hline 1 & 3354 & 20,962 & 20,962 & 3354 & 20,962 & 20,962 \\
\hline 2 & 2914 & 18,212 & 39,174 & 2914 & 18,212 & 39,174 \\
\hline 3 & 2559 & 15,993 & 55,168 & 2559 & 15,993 & 55,168 \\
\hline 4 & 1801 & 11,258 & 66,426 & 1801 & 11,258 & 66,426 \\
\hline 5 & 1615 & 10,095 & 76,521 & 1615 & 10,095 & 76,521 \\
\hline 6 & 1072 & 6700 & 83,221 & 1072 & 6700 & 83,221 \\
\hline 7 & 0.825 & 5156 & 88,377 & & & \\
\hline 8 & 0.564 & 3525 & 91,902 & & & \\
\hline 9 & 0.479 & 2991 & 94,893 & & & \\
\hline 10 & 0.334 & 2090 & 96,983 & & & \\
\hline 11 & 0.274 & 1713 & 98,696 & & & \\
\hline 12 & 0.126 & 0.785 & 99,481 & & & \\
\hline 13 & 0.074 & 0.465 & 99,946 & & & \\
\hline 14 & 0.009 & 0.054 & 100,000 & & & \\
\hline 15 & $2727 \mathrm{E}-17$ & $1705 \mathrm{E}-16$ & 100,000 & & & \\
\hline 16 & $-9644 \mathrm{E}-17$ & $-6028 \mathrm{E}-16$ & 100,000 & & & \\
\hline
\end{tabular}

Extraction method: Principal component analysis.

\section{The Main Search Results}

1) Motivation and difficulties (effects relative to hypothesis 1) (see Table 4: Correlation analysis between motivation and difficulties (combined scores)) in the pre-test. We remark in the pre-test that the correlation between motivation (lived experience, vicarious experience, physiological and emotional state, and sources information to self-efficacy sentiment) and difficulties is significant. The null hypothesis is rejected (H0: the absence of a relationship between those variables) (see Table 5: Correlation analysis between motivation and difficulties (combined scores)) in post-test. We remark in the post-test that the correlation between motivation and difficulties is substantial. The null hypothesis (H0) does not occur in the absence of a relationship between both variables. Therefore, there is one statically significant relationship between motivation and difficulties since the correlation coefficient is positive (0.05). Results demonstrate the existence of considerable covariance relations between the following elements: 1) motivation (combined scores) and difficulties; 2) lived experience and problems; 
Table 4. Correlation analysis between motivation and difficulties (combined scores) in the pre-test.

\begin{tabular}{cccc}
\hline & Pre-test & Program & Post-test \\
\hline experimental group & ++ & ++ & + \\
Group witness 1 & + & $\varnothing$ & + \\
Group witness 2 & $\varnothing$ & $\varnothing$ & + \\
\hline
\end{tabular}

Key: ++: pre-test post-test and program; +: pre-test and posttest; Ø: without pre-test administration; Ø: without program administration; ${ }^{* *}$ the correlation is significant at the level 0.01 (unilateral).

Table 5. Correlation analysis between motivation and difficulties (combined scores) in post-test.

\begin{tabular}{lcc}
\hline & The motivation (post test) & Learning difficulties (posttest) \\
\hline The motivation (post test) & 1000 & 0.283 \\
Pearson correlation & & 0.040 \\
Sig. (unilateral) & 89 & 39 \\
N & & 1000 \\
Learning difficulties (posttest) & 0.283 & \\
Pearson correlation & 0.040 & 49 \\
Sig. (unilateral) & 39 & \\
N
\end{tabular}

*The correlation is significant at the level 0.05 (unilateral).

3) Verbal persuasion and difficulties. However, correlation analysis revaluates absence of relations between these components: vicarious experience and difficulties physiological and emotional state and tests data sources of self-efficacy sentiment and problems. Therefore, we can conclude that the absence of motivation can be one of the most sources of students' difficulties. So, the first hypothesis can be confirmed.

2) The methodological training effect (conscious training to self-regulation, metacognitive, coping, control, and perseverance strategies, on motivation and mitigating difficulties) (results relative to hypothesis 2). (See Table 6: Synthesis of conscious training to strategies results (combined scores)). This conscious training to self-regulate, metacognitive, coping, control, and perseverance strategies through the methodological program accompaniment influence motivation and students' difficulties in the experimental group. Therefore, these all strategies' conscious exercise marks motivation and mitigates the student's experimental group. The second hypothesis is consequently confirmed.

3) The third hypothesis verification.

Results concord to signification that achievement of metacognitive strategies influences motivation to study. 
Table 6. Synthesis of conscious training to strategies results (combined scores).

\begin{tabular}{lcc}
\hline & $\begin{array}{c}\text { The motivation (post-test) } \\
\text { Pearson correlation } \\
\text { Sig. (unilateral) } \\
\text { N }\end{array}$ & $\begin{array}{c}\text { Pearson correlation } \\
\text { Sig. (unilateral) } \\
\text { N }\end{array}$ \\
\hline The motivation (post test) & 1000 & $429^{* *}$ \\
Pearson correlation & 89 & 0.000 \\
Sig. (unilateral) & $0.429^{* *}$ & 1000 \\
N & 0.000 & 74 \\
Strategies Pearson correlation & 64 & \\
Sig. (unilateral) & & \\
N & & \\
\hline
\end{tabular}

${ }^{*}$ The correlation is significant at the level 0.05 (unilateral).

\section{Results Discussion and Interpretation}

The research question demonstrates that the absence of motivation to study may be one of the other sources of freshman's difficulties that teacher or pedagogical accompaniment can act. Results also show the existence of statically proved covariance relations between: motivation (combined scores) and student sample difficulties; lived experience and problems (in pre-test); vicarious experience and problems (in post-test); verbal persuasion and issues (in pre and post-tests); sources of information to the self-efficacy sentiment and difficulties (in post-test). This analysis shows the absence of significant relation between physiological and emotional states and problems. Affirming the second answer inquiry question influenced those motivations by conscious training strategies: lived experience: The reaction to a student's historical school is a psycho-pedagogical tool that exceeds the transitional period between secondary and college studies. The accompaniment role consists in optimizing positive student thinking (as the baccalaureate, success against difficulties, do not abandon, to be at university, observing professional success opportunities perhaps offered by academic studies). Exercices allowed working on lived experience and the reflection about secondary college transition (example; ace has broken, locals juridic faculty podcast, tabula rasa, the outlet, blazon, genealogical tree, social mobility, live Parcours, Etc.). Vicarious experience: modeling or self-modeling makes it possible to modify the feeling of self efficacy sentiment. We used sensibilization and training cognitive and metacognitive toward modeling and self-modeling thinking. This training enables students to think about their person, choices, others' influences (parents, teachers, friends) about their options and personal characteristics. Medit on presence or absence of an individual, professional project, and even in the long term a carrier. Thinking about projects, comparing, and being 
conscious of environmental influence is an entrance toward modeling and self-modeling metacognitive genes. A self-efficacy sentiment Data sources can be intrinsic or extrinsic. Therefore, the student can be motivated healthy if his self-efficacy sentiment had intrinsic data sources. Methodological accompaniment program had between others target to training freshman to reject all «labels» they assume since childhood, family, and social environment. They learn to assess themselves by choosing and evaluate achievement targets. So, proposed activities focused on sources and quality of self-judgments and enhancing self-assessment abilities and performance. Meanwhile, results from methodological accompaniment are concretely satisfy especially on: targets fixation in courses starting; control to course concentration; metacognitive thinking about real learning and working difficulties; activities choices; learning strategies; assessment realization Versus no targets completion; tasks organization fellow their degrees of emergency, difficulty, and importance in the course. One psycho solution corroborates skills accompaniment, which is statistically proved, mainly the student sensibilization to studying environment at their concentration quantity and quality. This accompaniment program also allows fixing blocage signs, a motivation student's sources. Results also demonstrate that student's analysis difficulties ability was modified. Training's exams prediction and anticipation had tangible Changement upon analysis's making decisions difficulties under challenging revisions and exams. Experimental grow students had moved answers carrying awareness as to the importance of perseverance. This awareness attitude is very probably the result of the methodological training program. Results likewise reveal a beginning of metacognitive thinking student is about their learning strategies. 1) Self-regulation strategies include metacognitive, control, and motivation processes that involved the following indicators: fixing goals in starting courses. Since the beginning of our teaching sequence, we have (students and teachers in concert) designated learning goals, activities, and teaching materials. That choice allows a) establishment to an ambiance of confidence, freedom, autonomy, and responsible student; b) Teaching sequence is mutually assumed and followed by debate upon nature, origin, possible solutions, decisions difficulties. Debate conclusions follow from the importance of personal and professional project concepts and the necessity of methodological academic working training, and how to think about motivational learning strategies; 2) Metacognitive strategies involve the following indicators: fixing goals, controlling attention, difficulties sources thinking, choice activities, learning strategies thinking, and goals realization assessment. Several activities had contributed to developing metacognitive strategies, mainly: personal and professional project, motivation exercises, pre-required for studies, professional competencies of ancient laureate via video scope, et interview; 3) Control strategies involved establishing a personal time program, task organization following their importance, emergency and difficulties, place revisions choices, and managing resources. Methodological training allowed positive results upon this kind of strategy; 4) 
Motivational strategies imply these indicators: idioms, which translates inherent ideas to difficult situations, students' usual talks. We used verbal persuasion, teacher modeling, and self-modeling to return to his (student) achievements to attract demotivation sources; 5) Coping strategies are reflected on the following indicators: resourcefulness expression, management locking signs, metacognitive analysis to learning difficulties, and stress management; 6) Control strategies and perseverance appear behind these indicators: prediction and anticipation, task involvement, emotional metacognition. Rates presence versus absence in our course served us as students' persistence indicators. Some aspects were uninfluenced or little influenced by the methodological accompaniment program, as cognitive students' representations on their learning difficulties. We remark that activists are enabled to misconceptions kind of problems ever. Questionnaire item concreting most concrete activities (like taking notes, oral representation, summer) belonging models belongs to mental level and collecting difficulties data. In this research, it the difficult to incite st ents verbalizing their activities representations. Statistic results are inconclusive on emotional and physiological states management during courses. Questionnaire items are inappropriate $d$ the problem to look five months pedagogical sequence kinds. So, which type of as began probably modify in one other experimentation. Results signify that eh methodological program accompaniment makes possible self-regulation (metacognitive, management, motivational), coping, control, and perseverance strategies. Thus s, returning to the reciprocal determinism principle is crucial because we can realize the relation between learning motivates self-efficacy ting self-efficacy sentiment through methodological training and learning strategies enhancement. We can see and show the circularity and reciprocity of human motivation. Methodological accompaniment allows modifying students' motivation to mitigate learning difficulties and strengthen self-efficacy sentiment (main factor in the motivation concept according to sociocognitive approach).

\section{Conclusion}

The main objective of this research work is students' motivation and their higher education integration. Review of literature oriented our theoretical and practical choices toward sociocognitive approach and concept motivation definition. Witch definition allows useful subdivisions and indicators of the primary variable can be quickly being observable and measurable. Methodological accompaniment constitutes an adequate solution to components motivation in such context. To motivate students means training them on the method and learning strategies mitigating difficulties. Student can be able to resolve himself their studies problems enhancing their learning strategies.

\section{Conflicts of Interest}

The authors declare no conflicts of interest regarding the publication of this paper. 


\section{References}

Bandura, A. (1982a). Self-Efficacy Mechanism in Human Agency. American Psychologist, 37, 122-147. https://doi.org/10.1037/0003-066X.37.2.122

Bandura, A. (1982b). The Psychology of Chance Encounters and Life Paths. American Psychologist, 37, 747-755. https://doi.org/10.1037/0003-066X.37.7.747

Bandura, A. (1983). Self-Efficacy Determinants of Anticipated Fears and Calamities. Journal of Personality and Social Psychology, 45, 464-469. https://doi.org/10.1037/0022-3514.45.2.464

Bandura, A. (1984). Recycling Misconceptions of Perceived Self-Efficacy. Cognitive Therapy and Research, 8, 231-255. https://doi.org/10.1007/BF01172995

Bandura, A. (1986a). Auto-efficacité: Le sentiment d'efficacité personnelle. Traduit de I'Anglais par Jacques Lecomte. Bruxelles: DeBoek Université.

Bandura, A. (1986b). Social Foundations of Thought and Action: A Social Cognitive Theory. Englewood Cliffs, NJ: Prentice-Hall.

https://www.uky.edu/ eushe2/Bandura/Bandura1999AJSP.pdf

Bandura, A. (1986c). The Explanatory and Predictive Scope of Self-Efficacy Theory. Journal of Clinical and Social Psychology, 4, 359-373. https://doi.org/10.1521/jscp.1986.4.3.359

Bandura, A. (1988). Self-Regulation of Motivation and Action through Goal Systems. In V. Hamilton, G. H. Bower, \& N. H. Frijda (Eds.), Cognitive Perspectives on Emotion and Motivation (pp. 37-61). Dordrecht: Kluwer Academic Publishers. https://doi.org/10.1007/978-94-009-2792-6_2

Bandura, A. (2007). Much ado over a Faculty Conception of Perceived Self-Efficacy Grounded in Faculty Experimentation. Journal of Social and clinical Psychology, 26, 641-658.

Bandura, A. (2019). Applying Theory for Human Betterment. Perspectives on Psychological Science, 14, 12-15. https://doi.org/10.1177/1745691618815165

Barbeau, D. (1993). La motivation scolaire. Pédagogie collégiale Volume 7 nº 1 octobre 1993.

Benelazmia, A. (2002). Stratégies d'apprentissage et évaluation du système d'enseignement cas de l'enseignement secondaire au Maroc. Thèse de Doctorat, Rabat: Université Mohammed V Souissi, Faculté des Sciences de l'Education.

Bernard, P. Y., \& Michaut, C. (2018). Décrocher, et après? Les effets de l'expérience scolaire sur le devenir des élèves. Formation emploi 4.

Biemar, S., Romainville, M., Mettewie, L., Plumat, J., Alonso, A., Delvaux, S., Demiddeleer, S., Depuis, C., Hayez, C., Maraveliki, A., \& Vanhoolandt, C. (2020). Implémentation de dispositifs de différenciation et d'accompagnement personnalisé dans le ler degré de l'enseignement secondaire-août 2020.

Chesnaie, M. F. R. (1998). Vers l'autonomie-L'accompagnement dans les apprentissages. Paris: Hachette, Education.

DeKetele, J. M., \& Wouters, P. (1993). Les dispositifs de préparation des étudiants à l'enseignement supérieur et universitaire. RES Academia, 11, 41-72.

Delagaranderie, A. (1980). Les profils pédagogiques. Paris: Edition Le Centurion.

Delagaranderie, A. (1982). Le passage de l'enseignement secondaire à l'enseignement supérieur. Vie Pédagogique, 66, 4-8.

Delagaranderie, A. (1991). La motivation, son éveil, son développement.

Delagaranderie, A. (1999). La motivation. Paris: Le Centurion. 
Houart, M., \& Vastersavendt, G. P. (1996). De l’apprentissage de méthodes...à la motivation. Revue des Cahiers pédagogiques, $\mathrm{N}^{\circ}$ hors série sur la Motivation.

Houart, M., Bachy, S., Dony, S., Hauzeur, D., Lambert, I., Poncin, C., \& Slosse, P. (2019). La volition, entre motivation et cognition: Quelle place dans la pratique des étudiants, quels liens avec la motivation et la cognition? Revue internationale de pédagogie de l'enseignement supérieur, 35, 1. https://doi.org/10.4000/ripes.2061

Houssaye, J. (sous la direction de) (1993). La motivation. in La pédagogie: Une encyclopédie pour aujourd'hui. Paris: ESF, édition.

Kozanits, A. (2010). L'influence d'innovations pédagogiques sur le profil motivationnel et le choix de stratégies d'apprentissage d'étudiantes et d'étudiants d'une faculté d'ingénierie. Revue internationale de pédagogie de l'enseignement supérieur, 26, 2010. https://doi.org/10.4000/ripes.385

Langevin, L. (1996). Pour une intégration réussie aux études post secondaires. Montréal Les Editions Logiques.

Marzano, R., Brandt, R.S., Hughes, C.S., Jones, B.F., Pressein, B.Z, Rankin, S.C, \& Suhor, C. (1988). Dimensions of Thinking: A Framework for Curriculum and Instruction. Eric. https://eric.ed.gov/?id=ED294222

Merieu, P. (1987). Apprendre, oui mais comment? Paris: ESF.

Michaut, Ch. (2000). L'influence du contexte universitaire sur la réussite des étudiants. Thèse de Doctorat, Bourgogne: Université de Bourgogne.

Palincsar, A. S. (1986). Metacognitive Strategy Instruction. Exceptional Children, 53, 118-124.

Romainville, M. (2000). L'échec dans l'université de masse. Paris: L'Harmattan.

Romainville, M. (2006). La pratique enseignante en mutation à l'université. Bruxelles: DeBoek Université.

Romainville, M. (2007). Conscience, métacognition, apprentissage: Le cas des compétences méthodologiques. In La conscience chez l'enfant et chez l'élève (pp. 108-130). Sous la direction de Francisco Pons et Pierre André Doudin, Québec: Presses de l'Université de Québec.

Romainville, M., \& Crinon, J. (2020). Actualité de la métacognition. Cahiers pédagogiques, 75e année (563).

Viau, R. (1994). La motivation en contexte scolaire. Bruxelles: DeBoek University.

Vygostky, L.-S. (1978). Interaction between Learning and Development. http://www.psy.cmu.edu/ siegler/

Weidman, N. (1999). Constructing Scientific Psychology: Karl Lashley’s Mind-Brain Debates. Cambridge: Cambridge University Press.

https://doi.org/10.1017/CBO9780511529306

Zimmerman, B. J. (2002). Efficacité perçue et autorégulation des apprentissages durant les études. in Carré. Ph et Moisan, A (2002).

Zimmerman, B. J. (2015). A Personal Agency View of Self-Regulated Learning. In SelfConcept, Motivation and Identity: Underpinning Success with Research and Practice (pp. 83-114). Charlotte, NC: IAP Information Age Publishing.

Zimmerman, B. J. (2016). Exploring the Role of Peer Advice in Self-Regulated Learning: Meta-Cognitive, Social, and Environmental Factors. Teaching and Learning in Medicine, 28, 353-357.

Zimmerman, J. (1990). Self-Regulated Learning and Academic Achievement: An Overview. Educational Psychologist, 25, 3-17. https://doi.org/10.1207/s15326985ep2501_2 


\section{Appendix}

Components of motivation after Factorial analysis of the dimensions of motivation:

The lived experience.

Question 1: I have already repeated in primary: $\quad \square$ Yes $\quad \square$ No

Question 2: I have already repeated in college: $\quad \square$ Yes $\quad \square$ No

Question 3: I have already repeated in secondary: $\quad \square$ Yes $\quad \square$ No

Question 4: At the faculty, I:

$\square$ Am new $\quad \square$ Take module (s), specify which one (s):........

$\square$ I changed direction, (specify):

The vicarious experience.

Question 11: During my studies, I compare my experience to that of a:

$\square$ From my parents (father, sisters, father, cousin...).

$\square$ From my friends.

$\square$ From my teachers.

$\square$ Other, specify.

Question 14: To resolve my learning difficulties, I sometimes imitate a person:

$\square$ A parent $\quad \square$ Study mates $\square$ Person

Question 15: When trying to imitate a person, my attention is focused on:

$\square$ The marks she obtains.

$\square$ His way of preparing for his exams.

$\square$ His behavior in the face of difficulties.

Verbal persuasion.

Question 46: The teachers' assessments tell me the details of the activities I have to perform:

$\square$ yes $\quad \square$ no

The emotional and physiological state.

Question 72: During the course, I pay attention to some parts of the course: $\square$ Regularly.

$\square$ From time to time $\square$ Rarely

Question 73: My attention during lessons depends on the atmosphere in which I find myself:
$\square$ Regularly
$\square$ From time to time $\quad \square$ Rarely

Question 74: My attention during class depends on the teacher's way of doing:

$\square$ Regularly $\square$ Occasionally $\square$ Rarely

Question 75: My attention during class depends on the ideas I think of:

$\square$ Regularly $\quad \square$ From time to time $\quad \square$ Rarely

Question 29: After the presentation, the teacher's comments are:

$\square$ Encouraging $\square$ embarrassing $\square$ indifferent

Question 142: After each control, I criticize the teacher (s):

$\square$ yes $\quad \square$ no

E-Sources of information on the Sense of Personal Efficiency.

Question 61 Overall, in terms of studies, I judge myself: 

$\square$ Poor
$\square$ Average
$\square$ Excellent

Q57: Overall, feelings of pride, I owe them to my personal efforts:

$\square$ Yes

$\square$ no

Question 58: Overall, the feelings of pride, I owe them to the encouraging words of the teachers.

$\square$ Yes $\quad \square$ No

Question 59: Overall, the feelings of pride, I owe them to the encouragement of my parents.

$\square$ Yes $\quad \square$ No

Question 60: Overall, the feelings of pride, I owe them to the image I have with my comrades.

$\square$ Yes $\square$ No

Question 38: During the course I do not write anything down since I have the handout:

$\square$ Regularly $\quad \square$ From time to time $\quad \square$ Rarely 